\title{
Front Matter: Volume 10876
}

, "Front Matter: Volume 10876," Proc. SPIE 10876, Optical Interactions with Tissue and Cells XXX, 1087601 (12 April 2019); doi: 10.1117/12.2531977

SPIE. Event: SPIE BiOS, 2019, San Francisco, California, United States 


\section{Optical Interactions with Tissue and Cells XXX}

Hope Thomas Beier

Bennett L. Ibey

Editors

2-3 February 2019

San Francisco, California, United States

Sponsored and Published by

SPIE 
The papers in this volume were part of the technical conference cited on the cover and title page. Papers were selected and subject to review by the editors and conference program committee. Some conference presentations may not be available for publication. Additional papers and presentation recordings may be available online in the SPIE Digital Library at SPIEDigitalLibrary.org.

The papers reflect the work and thoughts of the authors and are published herein as submitted. The publisher is not responsible for the validity of the information or for any outcomes resulting from reliance thereon.

Please use the following format to cite material from these proceedings:

Author(s), "Title of Paper," in Optical Interactions with Tissue and Cells XXX, edited by Hope T. Beier, Bennett L. Ibey, Proceedings of SPIE Vol. 10876 (SPIE, Bellingham, WA, 2019) Seven-digit Article CID Number.

ISSN: 1605-7422

ISSN: 2410-9045 (electronic)

ISBN: 9781510623941

ISBN: 9781510623958 (electronic)

Published by

SPIE

P.O. Box 10, Bellingham, Washington 98227-0010 USA

Telephone +1 3606763290 (Pacific Time) · Fax +1 3606471445

SPIE.org

Copyright (C) 2019, Society of Photo-Optical Instrumentation Engineers.

Copying of material in this book for internal or personal use, or for the internal or personal use of specific clients, beyond the fair use provisions granted by the U.S. Copyright Law is authorized by SPIE subject to payment of copying fees. The Transactional Reporting Service base fee for this volume is $\$ 18.00$ per article (or portion thereof), which should be paid directly to the Copyright Clearance Center (CCC), 222 Rosewood Drive, Danvers, MA 01923. Payment may also be made electronically through CCC Online at copyright.com. Other copying for republication, resale, advertising or promotion, or any form of systematic or multiple reproduction of any material in this book is prohibited except with permission in writing from the publisher. The CCC fee code is $1605-$ $7422 / 19 / \$ 18.00$.

Printed in the United States of America by Curran Associates, Inc., under license from SPIE.

Publication of record for individual papers is online in the SPIE Digital Library.

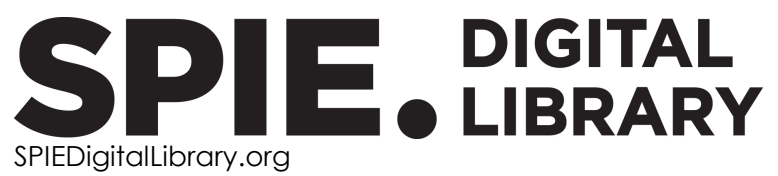

Paper Numbering: Proceedings of SPIE follow an e-First publication model. A unique citation identifier (CID) number is assigned to each article at the time of publication. Utilization of CIDs allows articles to be fully citable as soon as they are published online, and connects the same identifier to all online and print versions of the publication. SPIE uses a seven-digit CID article numbering system structured as follows:

- The first five digits correspond to the SPIE volume number.

- The last two digits indicate publication order within the volume using a Base 36 numbering system employing both numerals and letters. These two-number sets start with 00, 01, 02, 03, 04, 05, 06, 07, 08, 09, OA, OB ... 0Z, followed by 10-1Z, 20-2Z, etc. The CID Number appears on each page of the manuscript. 


\title{
Contents
}

\author{
$\checkmark \quad$ Authors \\ vii Conference Committee
}

NOVEL APPLICATIONS OF LASERS AND LIGHT IN BIOMEDICINE

1087602 Drug contact time dominates a necessary time for myocardial cells necrosis by a photodynamic reaction [10876-1]

1087603 Biofabrication of a vascular capillary by ultra-short laser pulses [10876-2]

1087606 Fluorescence spectroscopy of mouse organs using ultraviolet excitation: towards assessment of organ viability for transplantation [10876-5]

1087607 Setup and analysis to stretch adherent cells with light [10876-6]

OPTICAL PROPERTIES OF TISSUES I

$1087609 \quad$ Extraction of tissue optical parameters from diffuse reflectance measurements with a new able to count derivatives inverse Monte Carlo method [10876-8]

OPTICAL PROPERTIES OF TISSUES II

10876 OF Optical properties of thermally damaged porcine dermis and subcutaneous fat [10876-13]

ULTRAFAST PULSED LASER INTERACTIONS

10876 ol Nonlinear optical properties of water from $1150 \mathrm{~nm}$ to $1400 \mathrm{~nm}$ [10876-15]

10876 0J Mid-infrared femtosecond laser damage thresholds in skin [10876-16]

10876 OK Near infrared femtosecond laser-induced bacterial inactivation [10876-17]

\section{CELLULAR BIOMOLECULAR RESPONSE}

10876 OL Cell membrane molecular dynamics under a NIR focused laser [10876-18] 
10876 OM Comparison of various neural network-based models for retinal lesion analysis [10876-19]

NUMERICAL APPROACHES SIMULATING LASER-TISSUE INTERACTIONS AND RESPONSE

$108760 Q \quad$ Light propagation in highly scattering biological tissues analyzed by Green's functions [10876-24]

10876 OR Convolutional deep network for light propagation in heterogeneous bio-tissues [10876-25]

10876 OS Monte Carlo weighted algorithms for calculation of radiation characteristics and their derivatives in the biomedical optics problems [10876-26]

10876 OT MCmatlab: an open-source user-friendly MATLAB-integrated 3D Monte Carlo light transport solver with heat diffusion and tissue damage [10876-27]

10876 OV Comparison of various neural network-based models for retinal lesion analysis [10876-29]

\section{PHOTOTHERMAL INTERACTIONS}

10876 OX Interaction of thulium fiber laser with urinary stone: effect of laser parameter on fragmented particle size and retropulsion [10876-31]

10876 OY Primary investigations on defined thermal effects on soft tissue using a diode pumped Er:YAG laser system [10876-32]

\section{POSTER SESSION}

1087619 Soft tissue wound healing by low level laser [10876-36]

10876 1A Characterization of photophysical properties of curcumin for theranostics of neurodegenerative diseases [10876-37]

10876 1C Photothermal interactions with interstitial thermotherapy of vascular formations by infrared laser radiation of different wavelengths and the possibility of their ultrasonic evaluation [10876-39]

$108761 \mathrm{G}$ Antimicrobial photodynamic therapy applied to inactivation of salmonella enterica and staphylococcus aureus [10876-43]

$10876 \mathrm{lH} \quad$ Teaching light-tissue interactions: using technology for education [10876-44]

$1087611 \quad$ Fluorescence spectroscopy analysis of light-induced tooth whitening [10876-45] 
Proc. of SPIE Vol. 10876 1087601-6

Downloaded From: https://www.spiedigitallibrary.org/conference-proceedings-of-spie on 26 Apr 2023 Terms of Use: https://www.spiedigitallibrary.org/terms-of-use 


\section{Conference Committee}

Symposium Chairs

James G. Fujimoto, Massachusetts Institute of Technology (United States)

R. Rox Anderson, Wellman Center for Photomedicine, Massachusetts General Hospital United States) and Harvard Medical School (United States)

Symposium Co-chairs

Jennifer K. Barton, The University of Arizona (United States)

Wolfgang Drexler, Medical University of Vienna (Austria)

Program Track Chairs

E. Duco Jansen, Vanderbilt University (United States)

Jessica C. Ramella-Roman, Florida International University (United States)

Conference Chairs

Hope Thomas Beier, Air Force Research Laboratory (United States)

Bennett L. Ibey, Air Force Research Laboratory (United States)

Conference Program Committee

Joel N. Bixler, Air Force Research Laboratory (United States)

Randolph Glickman, The University of Texas Health Science Center at San Antonio (United States)

Steven L. Jacques, Oregon Health \& Science University (United States)

E. Duco Jansen, Vanderbilt University (United States)

Beop-Min Kim, Korea University (Korea, Republic of)

Alexander J. Makowski, Prozess Technologie (United States)

Jessica C. Ramella-Roman, Florida International University (United States)

Marissa Nicole Rylander, Virginia Polytechnic Institute and State

University (United States)

Zachary D. Taylor, University of California, Los Angeles (United States)

Robert J. Thomas, Air Force Research Laboratory (United States)

Alfred Vogel, Universität zu Lübeck (Germany)

\section{Session Chairs}

1 Novel Applications of Lasers and Light in Biomedicine

Bennett L. Ibey, Air Force Research Laboratory (United States) 
2 Optical Properties of Tissues I

Joel N. Bixler, Air Force Research Laboratory (United States)

3 Optical Properties of Tissues II

Adam R. Boretsky, Engility Corporation (United States)

$4 \quad$ Ultrafast Pulsed Laser Interactions

Ibtissam Echchgadda, Air Force Research Laboratory (United States)

5 Cellular Biomolecular Response

Michael P. DeLisi, Engility Corporation (United States)

6 Numerical Approaches Simulating Laser-Tissue Interactions and Response Robert J. Thomas, Air Force Research Laboratory (United States)

7 Photothermal Interactions

Michael L. Denton, Air Force Research Laboratory (United States) 